\title{
General Tax Provisions and Procedures Issues on the Omnibus Law in Indonesia
}

\author{
Prianto Budi Saptono*, Cyntia Ayudia**,,Muhammad Akbar Aditama*** \\ *Faculty of Administrative Sciences, Universitas Indonesia \\ *** Pratama-Kreston Tax Research Institute \\ ***Pratama-Kreston Tax Research Institute \\ DOI: 10.29322/IJSRP.11.09.2021.p11744 \\ http://dx.doi.org/10.29322/IJSRP.11.09.2021.p11744
}

\begin{abstract}
This study aims to analyze policy issues regarding general provisions and tax procedures based on the tax omnibus law idea. In 2020, Law No. 28 of 2007 concerning General Tax Provisions and Procedures as ceremonial law has undergone substantial and fundamental amendments. The amendments are in Law No. 11 of 2020 concerning Job Creation. This research is a descriptive qualitative study using data techniques such as documentation and literature studies. The study concluded that the omnibus law's purpose was to encourage voluntary taxpayer compliance and increase legal certainty. This omnibus law policy shows the government's desire to provide justice and convenience to taxpayers. The rearrangement of administrative tax sanctions (interest, fines, increases) and interest returns that refer to the reference interest rate and the uplift factor component has met three indicators: time value of money, proportionality principle according to the error rate, and the principle of guilt. Also, regulatory amendments to achieve legal certainty can positively impact more optimal tax revenue in the future, reduce compliance costs, and reduce tax avoidance. However, this regulatory change needs to be in line with clear implementing regulations, not multiple interpretations, and still prioritizing socialization to the public.
\end{abstract}

Index Terms- general tax provisions, omnibus law, tax compliance

\section{INTRODUCTION}

$\mathrm{T}^{\mathrm{s}}$ ax compliance is a crucial issue in both developed and developing countries. Taxpayers who do not comply will do tax evasion or evasion, causing tax revenue to decrease. Tax compliance also has a close relationship with tax law enforcement. Sanctions are an essential aspect of guaranteeing the state's right to tax revenue and ensuring that taxpayers comply with the law's provisions (Riyanto, 2020). However, Indonesia's formal tax compliance tends to fluctuate and has not been optimal even though it shows that registered taxpayers increase yearly. Some of the factors that cause low compliance are Indonesia's high tax compliance costs, the bureaucracy, and tax officials. Also, tax morale is the key to determining the extent to which taxpayers fulfill their tax obligations voluntarily. In the taxation context, tax morale is an intrinsic motivation to pay taxes. Individuals' willingness or moral obligation to pay taxes or their belief in contributing to society by paying taxes (Torgler, 2005, p. 526). Tax morale will guarantee public contributions through the tax system with or without a coercive approach, sometimes even in the absence of tax laws.

Empirically, tax morale has an essential role in increasing voluntary compliance in developed and developing countries (OECD, 2019; Ali, Fjeldstad, \& Sjursen, 2014). Various surveys by Afrobarometer, Asiabarometer, and Latinobarometro concluded that several aspects affect the level of tax morale, including satisfaction with public services, trust in government, perceptions of corruption, tax administration, and the imposition of sanctions by tax authorities for taxpayer violations (OECD, 2019). Therefore, in building tax morale, it must be through participatory and transparent tax policy formulation, a tax system that can reduce inequality, and tax imposition that reflects aspects of justice and legal certainty (Darussalam, 2020). The Directorate General of Taxes explained that one of the efforts to optimize tax revenue is applying the omnibus law. Tax optimization is from broadening the tax base and improving policy and administration, especially legal certainty. Minimizing tax uncertainty is the basis for achieving a suitable taxation model for businesses (Owens, 2019). The leading causes of tax uncertainty are tax regulations' complexity, including documentation requirements, inconsistent tax authorities' decisions, and the inability to achieve tax certainty through the roll-out mechanism (OECD, 2017).

Based on the 2020 National Legislation Program, the Indonesian government has proposed two Bills that use the omnibus law method, namely the Bill on "Tax Provisions and Facilities for Strengthening the Economy" and the Bill on "Job Creation." In the plenary session, the People's Representative Council of the Republic of Indonesia (DPR RI) has officially ratified the Job Creation Bill (RUU) into Law No. 11 of 2020 on November 2, 2020, in the plenary session. The Job Creation Law implements the idea of the omnibus law as a legal breakthrough that can solve various problems in several overlapping regulations through synchronization into one law comprehensively. Garner in Black's Law Dictionary (2009, p. 186) defines the concept of the omnibus bill as "a single bill containing various distinct 
matters, usually drafted in this way to force the executive either to accept all the unrelated minor provisions or to veto the major provision." Another definition is "a bill that deals with all proposals relating to a particular subject." An omnibus bill means drafting a new law covering various content types and amending several laws at once. This concept generally applies in the country with common-law systems, such as the United States.

The Law on Job Creation amends 78 Laws consisting of 15 Chapters and 186 Articles. It includes the taxation cluster listed in Part Seven, Chapter VI concerning Ease of Doing Business and is divided into Articles 111 to Article 114. The Ease of Doing Business in the taxation sector needs to amend various statutory provisions in the not distant future. The Omnibus law simultaneously changes several tax regulations: Law No. 28 of 2007 concerning General Tax Provisions and Procedures (Ketentuan Umum dan Tata Cara Perpajakan; KUP). This effort is an efficient and effective step compared to waiting for a discussion of each taxation law. The tax cluster in the Job Creation Law has various objectives, including increasing employment and adjusting various regulatory aspects related to the investment ecosystem. In particular, this regulation helps encourage economic recovery, supporting economic transformation to avoid middle-income traps, encouraging increased investment competitiveness amidst the global economic slowdown, and suppressing high-cost economies (Darussalam, 2020).

Furthermore, Article 113 regulates the amendment and addition of articles to the KUP Law, encouraging voluntary tax compliance and increasing legal certainty. This amendment is fundamental through rearranging administrative tax sanctions, including in exchange for interest, because the KUP Law is a formal law covering the imposition of sanctions and reporting time. This research will focus on analyzing policy issues in the KUP Law in Law 11/2020.

\section{CONCEPTUAL FRAMEWORK}

\section{A. Culpability Principle}

In criminal law, culpability is another term for the principle of no punishment without error (geen straaf Zonder schuld). That is, it cannot punish someone if their guilt is not proven. Therefore, the basis of the culpability principle is proof of error (schuld) either on purpose or due to negligence. The principle of culpability aims to determine the level of punishment to taxpayers commensurate with taxpayers' mistakes (Rowell \& Flood, 2017).

Waerzeggers et al. (2019), in "Designing Interest and Tax Penalty Regimes," suggests that an effective tax sanction regime must cover various sanctions, both monetary and non-monetary. There are three ways to design monetary penalties: (a) fixed penalties, (b) penalty percentage, (c) gradual punishment. The gradual implementation of penalties is discretionary and a case-by-case basis by the tax authorities. Accordingly, the imposition of penalties may increase depending on the taxpayer's errors, including the taxpayer's repeated waivers of the provisions ("gradual penalties"). This approach is most appropriate when the offense involves varying degrees of error by the taxpayer or engaging in repeated inappropriate behavior. The aim is to achieve fair results so that the sanctions' severity is proportional to the perpetrator's guilt level.

Administrative sanctions rules must comply with the following design principles: (i) easy for taxpayers to understand and accessible for tax authorities to regulate; (ii) fair, for example, by treating taxpayers equally; apply sanctions consistently for violations of similar tax obligations; impose sanctions uniformly concerning all tax laws; grant review rights; and imposed with due regard to facts and mitigating circumstances; (iii) proportional, for example by providing additional sanctions based on the taxpayer's error, and taking into account the level of losses caused by non-compliance; and (iv) effective, by preventing non-compliance while maintaining proportionality and fairness. Sentencing may also consider taxpayers' attempts to correct initial non-compliance (through the reward feature), provided the regime does not become too complex to understand and operate.

\section{B. Proportionality Principle}

Referring to Her Majesty's Revenue and Customs (HMRC) in the United Kingdom, the principle of justice and legality presupposes that legal remedies for violating the law in all cases must be proportional (adequate) to the violation itself. Legal remedies must also be following legal objectives that are important to the public and must not limit a person to more than is objectively necessary to achieve these objectives. Laws and regulations must ensure proper and timely tax payments. Legal certainty ensures the law's effectiveness, and various measures can be used, such as penalties and interest. However, all these actions must be proportional (Audzevicius, 2011). The law states that government activities, including taxation, must be proportional to the desired goals and achieve a fair balance between the public interest in enforcing or collecting taxes and the taxpayer's right not to be punished unfairly (Needham, 2012). The importance of fairness and proportionality suggests that unfair or disproportionate penalties can result in continuous non-compliance (Lane, 2015). The imposition of sanctions must fulfill the principle of proportionality (Pistone, 2019, p. 145). This aspect aims to distinguish the degree of taxpayer error committed and sanctions' impositions proportional to errors (Diaz, 2016). The proportional design of sanctions can ensure the achievement of the objectives of the imposition of sanctions itself. Moreover, there is a close relationship between the purpose of imposition of sanctions and the level of sanctions (Vanistendael, 1996, p. 9).

As a general rule, the punishment's severity should be commensurate with the taxpayer's error rate. Governments need to carefully calibrate punitive regimes to achieve the dual goals of prevention and justice. On the one hand, sanctions should not be so low that they do not incentivize taxpayers to comply with their tax obligations. Besides, penalties should not be too severe, leading to increased corruption (especially when the tax authorities are vulnerable to corrupt practices) and injustice if they do not apply sanctions consistently to all taxpayers who commit violations due to weakness in detection. Also, sanctions that are too high can result in 
ineffective implementation. Policymakers need to consider error and mitigation factors in determining the appropriate level of punishment. Anton Lane (2015), in "Proportionality and Penalties," outlines five principles by which HMRC relates to penalties: (i) to promote compliance and prevent non-compliance (the purpose of using penalties is not to increase revenue); (ii) is proportionate to the offense and may take into account past behavior; (iii) the application of penalties by adequately recognizing the compliant and noncompliant taxpayers; (iv) poses a credible threat. In this case, it must increase the fine and collect it cost-effectively; and (v) a consistent and standardized approach (variation in sanctions will be necessary to consider customer behavior and specific taxes).

\section{Certainty Principle}

Legal certainty can is things that law can determine concretely (Prayogo, 2016, p. 193; Apeldoorn, 1990). In this case, legal certainty is one of the law enforcement requirements to guarantee that someone who has rights according to the law can obtain his rights and guarantee the implementation of decisions. Maria S.W. Sumardjono (1997) argues that normatively, legal certainty requires the availability of statutory instruments to support law enforcement. Empirically, implementing these laws and regulations needs to be consistent and consistent with the supporting human resources. In legal formation, a regulation is made and promulgated because it regulates clearly and logically, which means that it does not cause doubts and can be accepted to become a norm system that does not clash or conflict with other norms (Prayogo, 2016). The tax policy generated in positive law can be optimal, but there are still loopholes that can create gray areas or multiple interpretations.

The law has the task of creating legal certainty because it aims to create order in society. According to Adam Smith (1776, p. 718), the principle of legal certainty is a tax — which must be paid by each individual - must be absolute and not arbitrary. The timing of payment, the method of payment, and the amount due must all be clear to each individual and every taxpayer (Smith, 1776; McLure, Charles E., 2019). Tax regulations must be understandable so that taxpayers know where they stand (OECD, 2014, p. 30). Without clear guidelines, taxpayers will find it challenging to carry out their obligations and rights (Rosdiana \& Irianto, 2014, p. 168). The principle of certainty cannot be separated from the law itself because both are conceptually related (Bertea, 2008, p. 25). The principle of certainty is part or criterion of the ease of administration and compliance principle because it is related to the system and taxation implementation (Wagner A., 1883, p. 11; Seligman, 1920). Certainty in tax matters is an important goal. One of the practical tools to increase tax certainty is a dispute resolution mechanism that is fair and independent, accessible to taxpayers, and helpful in resolving disputes immediately. The detailed tax collection instructions, follow-up decisions, and other legal interpretations are required to increase legal certainty (OECD, 2017, p. 7).

\section{RESEARCH METHOD}

This research is descriptive qualitative research that focuses on general policy provisions and tax procedures issues in the omnibus law. Creswell (2014) states that qualitative research starts with assumptions and uses an interpretive or theoretical framework that shapes or influences the study of research problems related to individuals or groups' meaning on a social or human problem. Research describes social phenomena and their characteristics by prioritizing social reality (Wagner, Kawulich, \& Garner, 2012) and is followed by theoretical studies or relevant perspectives to help understand focused social phenomena. The aspects described in detail in this study include amendments to the ceremonial law in the omnibus law, which contains several fundamental rules. The data collection technique uses documentation study through literature, both in legislation and studies with qualitative data analysis.

\section{RESULT AND DISCUSSION}

Law No. 6 of 1983, as last amended by Law No. 16 of 2009, regulates the General Tax Provisions and Procedures (KUP). The opinion of Richard K. Gordon (1996) in the "Law of Tax Administration and Procedure" is relevant to conditions in Indonesia. In principle, the KUP Law's substance is an administrative tax law covering many problems with complex and changing characteristics. Conceptually, formal tax law aims to provide guarantees for the proper implementation of material tax law, namely laws and regulations in the field of taxation, including Income Tax Law, Value Added Tax Law, and Property Tax Law. Therefore, the formal tax law generally regulates taxpayer's and tax authorities' rights and obligations and contains procedures for the administration or procedures for determining a tax debt, collection, and sanctions.

Unlike the case with regulations that are material provisions, the KUP Law is a formal tax law that does not have a fundamental administration principle. However, many concepts underlie the regulations or articles in it. The KUP Law is prepared based on a hotchpotch of rules approach, sometimes interrelated, not closely related or not even based on arbitrary consideration. For example, tax procedures or procedures are related to the ease of administration principle, while the imposition of sanctions is in line with the principle of justice (equity). Some of the KUP rules reflect the KUP Law system, which refers to the organization's functional, temporal, and legal principles. The functional aspects include the functions of administration, supervision, counseling, punishment, and investigation.

Meanwhile, the temporal aspect refers to the order in which the tax obligations implementation, starting from the ownership of a Taxpayer Identification Number (Nomor Pokok Wajib Pajak; NPWP), filling out Tax Returns (Surat Pemberitahuan; SPT), paying payable taxes and reporting, accounting, auditing, checking preliminary evidence, to investigating. Furthermore, the legal aspect includes definition, taxpayer rights, sanctions, and interest compensation. When these three aspects are combined, it can form a coherent legal structure following the bureaucracy and procedures regulated in the KUP Law. 
The logical consequence of including formal tax law provisions in statutory regulations is that it must go through law if there is a change. Amendments to law need to go through procedures that are not easy and require a relatively long time. As a formal tax law, the KUP Law has undergone several changes with the last amendment in Law No. 11 of 2020 concerning Job Creation ("Law 11/2020"). Table 4.1 summarizes the dynamics of the amendments to the KUP Law as follows:

Table 4.1 Dynamics of Amendments to the KUP Law

\begin{tabular}{|c|l|r|r|c|}
\hline No. & \multicolumn{1}{|c|}{ KUP Law Number } & Date of promulgation & Validity period & Amendment \\
\hline 1. & Law No. 6 of 1983 & December 31, 1983 & January 1, 1984 - present & - \\
\hline 2. & Law No. 9 of 1994 & November 9, 1994 & January 1, 1995 - present & I \\
\hline 3. & Law No. 16 of 2000 & July 17, 2007 & January 1, 2001 - present & II \\
\hline 4. & Law No. 28 of 2007 & December 31, 2009 & January 1, 2008 - present & III \\
\hline 5. & Law No. 16 of 2009 & May 18, 2020 & May 18, 2020 - present & IV \\
\hline 6. & $\begin{array}{l}\text { Government Regulations in place of } \\
\text { Law No. 1 of 2020 (Law No. 2 of } \\
\text { (Only revoking the enforcement of } \\
\text { several time-frame provisions relating } \\
\text { to state financial policies for handling } \\
\text { the Covid-19 pandemic) }\end{array}$ & & November 2, 2020 - present & V \\
\hline 7. & $\begin{array}{l}\text { Law No. 11 of 2020 } \\
\text { (Omnibus law approach) }\end{array}$ & November 2, 2020 & Novem \\
\hline
\end{tabular}

Source: Processed by the author

The amendments include amendments, deletions, and additions to several articles. A rearrangement of administrative tax sanctions and interest returns refers to the reference interest rate to encourage taxpayer compliance and voluntary compliance while still providing a deterrent effect. Amendments to the provisions on this sanction include Article 8, Article 9, Article 11, Article 13, Article 14, Article 17B, Article 19, Article 38, and Article 44B.

Apart from that, the main objectives of the amendment are to increase legal certainty, including (i) tax penalties which have resulted in a decision not to issue tax assessments; (ii) issuance of a Tax Collection Letter that expires 5 (five) years; (iii) the issuance of a Tax Collection Letter becomes invalid to collect interest compensation which should not be the right of the taxpayer; (iv) application of one type of administrative sanction; and (v) termination of preliminary evidence examination and investigation. Additional provisions include the basis of issuance of Tax Underpayment Assessment (Surat Ketetapan Pajak Kurang Bayar; SKPKB) and the provision of interest compensation for the grant of legal remedies filed taxpayers causing tax overpayment. Law 11/2020 removes Article 13A, Article 27A, and inserts Article 27B.

\section{A. Purpose of The Omnibus Law}

The first discussion in this study relates to the purpose of the omnibus law to encourage voluntary compliance. The changing subject includes rearranging administrative tax sanctions (interest, penalties, and increases), including interest compensation. Sanctions have the primary function of enforcing legal compliance. Even so, sanctions can also affect public perceptions of paying taxes voluntarily (OECD, 2019). Theoretically, tax sanctions consist of two, namely administrative sanctions and criminal sanctions. In Indonesia, administrative tax sanctions generally consist of interest sanctions, fines, and increase sanctions. In the context of the imposition of sanctions as stipulated in the KUP Law, the imposition of administrative sanctions applies to taxpayers who violate the fulfillment of tax obligations.

Referring to the description in the Academic Paper of the Bill "Taxation Provisions and Facilities for Strengthening the Economic," stipulates that there is a risk of economic slowdown due to disruption of the taxpayer's business continuity. One of the contributing factors is the amount of tax, customs, and excise administrative sanctions that the taxpayer must bear due to negligence in carrying out tax obligations. The imposition of administrative sanctions in Law 28/2007 in interest at a fixed rate of $2 \%$ (two percent) per month of underpaid tax is deemed not to fulfill the principle of fairness in tax treatment for taxpayers' mistakes. In this case, it does not differentiate the types of violations that are the basis for the imposition of sanctions, including determining whether the issuance of sanctions is due to the taxpayers' voluntary self-assessment or the issuance of sanctions from the Directorate General of Taxes (official assessment). For example, the sanctions for correcting Tax Returns are higher than for auditing, causing a distortion effect for taxpayers to choose the audit process than making a voluntary correction.

Furthermore, in the provisions of Law 28/2007, there are administrative sanctions that recognize the maximum imposition limit of 24 months. However, some regulations do not contain provisions regarding the imposition limit, resulting in an interest penalty that exceeds the tax principal. Several sanctions like this can positively disrupt the taxpayer's business continuity, specifically if the tax office does not immediately issue a Tax Collection Letter. The number of administrative sanctions can be burdensome and does not encourage 
taxpayer compliance. It tends to interfere with the sustainability of the taxpayers' business activities, which leads to avoiding the fulfillment of tax obligations.

To strengthen the economy, the government enacts Law 11/2020 on Job Creation to reduce investment barriers by rearranging administrative tax sanctions that ease taxpayers' burden, are fair, and encourage voluntary compliance. The imposition of administrative sanctions must have a deterrent effect and provide tax education to taxpayers. In connection with efforts to encourage voluntary tax compliance, the government is trying to redesign tax administration sanctions. Table 4.2 summarizes the comparison of interest administration sanctions according to the KUP Law and its amendments in the Job Creation Law as follows:

Table 4.2 Comparison of Interest Administration Sanctions According to the KUP Law and the Job Creation Law

\begin{tabular}{|c|c|c|c|}
\hline Article in KUP Law & The imposition of Administrative Sanctions & $\begin{array}{l}\text { Amount of } \\
\text { Sanctions } \\
\text { According to UU } \\
\text { KUP 28/2007 }\end{array}$ & $\begin{array}{l}\text { Changes in the } \\
\text { Job Creation } \\
\text { Law 11/2020 }\end{array}$ \\
\hline Article 19 paragraph (1) & $\begin{array}{l}\text { The imposition of interest sanctions on the Tax } \\
\text { Underpayment Assessment Letter, Correction Decree, } \\
\text { Objection Decision, Decision on Appeal, or Judicial } \\
\text { Review increases tax payable. In this case, the } \\
\text { underpayment remains at the due date of settlement. } \\
\text { (Billing Interest) }\end{array}$ & \multirow[t]{8}{*}{$\begin{array}{l}\text { Interest sanction is } \\
2 \% \text { per month of } \\
\text { the underpaid tax } \\
\text { amount }\end{array}$} & \multirow[t]{3}{*}{$\begin{array}{l}\text { Interest rate per } \\
\text { month* of } \\
\text { underpaid tax } \\
*(\text { Reference } \\
\text { interest rate }+ \\
0 \%) \div 12\end{array}$} \\
\hline Article 19 paragraph (2) & $\begin{array}{l}\text { Taxpayers who can pay in installments or postpone tax } \\
\text { payments } \\
\text { (Installments or postponement of tax payments) }\end{array}$ & & \\
\hline Article 19 paragraph (3) & $\begin{array}{l}\text { Taxpayers can postpone the submission of the Annual Tax } \\
\text { Return. It turns out that the quick calculation of the tax due } \\
\text { as referred to in Article } 3 \text { paragraph (5) is less than the } \\
\text { actual amount of tax due. } \\
\text { (Underpayment of postponement of submission of Annual } \\
\text { Tax Return) }\end{array}$ & & \\
\hline Article 8 paragraph (2) & Underpayment of Correction of Annual or Periodic SPT & & \multirow{5}{*}{$\begin{array}{l}\text { Interest rate per } \\
\text { month* of } \\
\text { underpaid tax }\end{array}$} \\
\hline Article 8 paragraph $(2 a)$ & $\begin{array}{l}\text { Taxpayers correct their Periodic Tax Return (before the } \\
\text { audit), which results in higher tax debt. }\end{array}$ & & \\
\hline Article 9 paragraph $(2 \mathrm{a})$ & Late payment of Periodic Income Tax & & \\
\hline Article 9 paragraph $(2 b)$ & $\begin{array}{l}\text { Late payment of Annual Income Tax or Income Tax Article } \\
29\end{array}$ & & \\
\hline Article 14 paragraph (3) & $\begin{array}{l}\text { Issuance of Tax Collection Letter by DGT due to: } \\
\text { the i. The income tax that is not paid or underpaid; } \\
\text { ii. Based on the research results, some underpaid taxes due } \\
\text { to writing errors/miscalculations } \\
\text { (Income tax in the current year is not paid/underpaid or } \\
\text { from the results of the audit there is a tax underpayment as } \\
\text { a result of writing errors/miscalculations) }\end{array}$ & & \\
\hline Article 8 paragraph (5) & $\begin{array}{l}\text { Disclosure of incorrect Tax Return after inspection but not } \\
\text { yet issued a tax assessment. } \\
\text { (Underpaid tax that arises as a result of disclosing } \\
\text { incorrect Tax Return filling) }\end{array}$ & $\begin{array}{l}\text { Increase sanction is } \\
50 \% \text { of the } \\
\text { underpaid tax } \\
\text { amount }\end{array}$ & $\begin{array}{l}\text { Interest rate per } \\
\text { month* of } \\
\text { underpaid tax } \\
*(\text { Reference } \\
\text { interest rate }+ \\
10 \%) \div 12\end{array}$ \\
\hline Article 13 paragraph (2) & $\begin{array}{l}\text { Issuance of underpayment of tax assessments because the } \\
\text { taxpayer does not pay or does not pay taxes due to matters } \\
\text { based on Article } 13 \text { paragraph } 1 \text { letters (a) to (e) of the } \\
\text { KUP Law. } \\
\text { (Sanction of Underpaid Tax Assessment) }\end{array}$ & $\begin{array}{l}\text { Interest sanction is } \\
2 \% \text { per month of } \\
\text { the underpaid tax } \\
\text { amount }\end{array}$ & $\begin{array}{l}\text { Interest rate per } \\
\text { month* of } \\
\text { underpaid tax }\end{array}$ \\
\hline
\end{tabular}




\begin{tabular}{|c|c|c|}
\hline Article 13 paragraph $(2 a)$ & $\begin{array}{l}\text { Issuance of Tax Underpayment Assessment Letter because } \\
\text { the Taxable Entrepreneur has not delivered the goods or } \\
\text { services but has received returns / has credited the input tax } \\
\text { as referred to in Article } 9 \text { paragraph (6a) of the VAT Law. } \\
\text { (Refund of input tax from non-producing taxable } \\
\text { entrepreneurs) }\end{array}$ & $\begin{array}{l}*(\text { Reference } \\
\text { interest rate }+ \\
15 \%) \div 12\end{array}$ \\
\hline
\end{tabular}

Source: Processed by the author

Referring to Table 4.2 above, the amount of administrative sanctions in the form of interest per month refers to the reference interest rate set by the Minister of Finance and which is in effect on the starting date of the calculation of the sanctions divided by 12 (twelve), plus the uplift factor. The maximum number of months is 24 (twenty-four) months. As an additional component in the calculation formula for tax administration sanctions, the uplift factor aims as a stimulus to encourage voluntary compliance. The new sanction imposition scheme uses the uplift factor to differentiate the sanctions amount according to the taxpayer's error rate. There are four different formulas for imposing administrative sanctions in the form of interest depending on the uplift factor starting from $0 \%$ (zero percent), $5 \%$ (five percent), $10 \%$ (ten percent), and 15\% (fifteen percent). It reflects the level of taxpayers in the implementation of the self-assessment regime.

In general, there are two approaches to determining the penalty interest rate. This approach includes (i) sanctions on interest rates with a fixed value (fixed rate) that does not change and (ii) sanctions on a flexible interest rate (flexible rate) based on the high and low market interest rates. The amount of the fixed rate interest penalty of $2 \%$ (two percent) has never changed since the enactment of Law No. 6 of 1983, although it has undergone several changes (Mulyodiwarno, 2007, p. 29).

According to Table 4.2, there is a reasonably fundamental change in the omnibus law provisions regarding interest sanctions. The government will change some of the interest sanctions from the fixed-rate regime to a flexible rate. The flexible rate is determined based on the market interest rate plus a certain mark-up percentage. This approach adjusts for a certain period and a floating rate that constantly changes according to the prevailing trend of the Bank Indonesia benchmark interest rate. The change in the tariff approach to the interest sanction reflects the government's severe steps in creating a better tax administration system.

Before the amendment to the KUP Law in the Job Creation Law, the tax administration sanction in the form of interest was set at one rate or beaten at an average of $2 \%$ (two percent) per month of the tax underpayment. For example, these sanctions apply to all underpayments violations due to annual and periodic Tax Returns corrections. This provision is not much different when the interest sanction is $2 \%$ (two percent) for underpayment due to issuing a tax assessment letter (Surat Ketetapan Pajak; SKP) by the tax authorities. Through the amendments contained in the Job Creation Law, the administrative sanction rate in the form of interest is no longer $2 \%$ (two percent) for all types of violations resulting in an underpayment of taxes, but rather a stipulation by the Minister of Finance and based on the reference interest rate divided by 12 (twelve). Several indicators reflect the sanctions policy's formulation's suitability in assessing whether the changes to tax administration sanctions in the omnibus law reflect fairness and equality.

The first indicator, the tax interest sanction, must be higher than the market interest rate. Fulfilling the criteria below market value is necessary so that taxpayers can prioritize or prioritize the obligation to pay off taxes compared to paying debt obligations or other needs (Waerzeggers, Hillier, \& Aw, 2019). Determining the interest sanction based on the market reference interest rate plus a certain percentage is an ideal recommendation and does not require regular government adjustments (Crawford, 2013). Interest fixed-rate sanctions do not comply with the principle of justice because they are not relevant to the time value of money principle. It can be too high or too low from certain economic conditions. However, interest rates still have the advantage of being definite of the payment value for a certain period without any risk in increasing the benchmark interest rate by Bank Indonesia. However, the formulation of an administrative sanction amount needs to consider the value principle for money over time to provide fairness to taxpayers. Through the omnibus law in the Job Creation Law, the government is trying to change the approach to determining the interest rate sanction from a fixed rate to a flexible rate. The floating rate has a variable nature because it depends on applying the reference interest rate from Bank Indonesia. Bank Indonesia constantly evaluates the reference interest rate in a certain period. The calculation of administrative sanctions in the form of interest using the reference interest rate can encourage taxpayers to immediately pay off their tax obligations by considering the equal amount of the administrative sanctions with the results derived from the investment. Based on this formula, the sanctioned amount is neither too high nor too low, so the determination of the interest rate sanction reflects the ideal basic formula.

The second indicator, The imposition of sanctions, must fulfill the principle of proportionality (Pistone, 2019, p. 145). This aspect aims to distinguish the degree of mistake so that sanctions' imposition is proportional to the taxpayer's mistakes (Diaz, 2016). The proportional design of sanctions can ensure the achievement of the objectives of the imposition of sanctions itself. Moreover, there is a close relationship between the purpose of imposition and the level of the sanction (Vanistendael, 1996, p. 9). Through the omnibus law, the government seeks to distinguish the degree of taxpayer's mistakes. Sanctions that are too high and burdensome (disproportionate) can encourage taxpayers to avoid the tax system and encourage collusion to be free from these disproportionate sanctions. Thus, the goal of increasing compliance is even more challenging to achieve.

The application of the principle of proportionality for the determination of sanctions and fines must meet the criteria cooperation stability (benefits from achieving the objectives of the imposition of sanctions and fines); (ii) need (the need for sanctions and fines when other alternative measures are not possible; and (iii) proportionality (balance between objectives and sanctions or fines used) itself (Diaz, 2016). The administrative sanction scheme in the omnibus law reflects the principle of proportionality because the imposition of 
sanctions considers the addition of other factors, in the form of a specific additional percentage other than interest with legal power. A proportional tax sanction arrangement can shape taxpayers' perception of a better tax system (Darussalam, Septriadi, \& Kristiaji, 2020). The additional varying percentages can further provide a fair arrangement. Furthermore, a deeper understanding of the factors that influence taxpayers' perceptions of the tax system and willingness to pay taxes is a starting point for improving tax morale (OECD, 2019, p. 11). In principle, tax morale is the reason for the taxpayer to pay taxes. Therefore, increasing tax morale can also increase tax revenue. Thus, it can reduce behavior to make payments or reporting incorrectly or not on time.

Furthermore, for the rearrangement of administrative sanctions to run effectively, it requires support for improving tax administration with an orientation towards fulfilling taxpayers' rights. Guaranteed taxpayer rights can create justice and legal certainty. Thus, it reduces compliance costs and tax collection (Silvani \& Baer, 199. 9).

The third indicator, the formation of interest and fines following the culpability principle, the principle of culpability aims to determine the level of penalty given to taxpayers commensurate with the mistakes made by taxpayers (Rowell \& Flood, 2017). Article 6 paragraph (2) Law No. 48 of 2009 concerning Judicial Power stipulates that "No one can be charged with a criminal offense except based on valid evidence according to law, and the court has a belief that a person has been guilty of his actions according to the indictment." When a violation occurs, first look at the taxpayer's mistakes and adjust it to the type of sanction to create justice (Darussalam, Septriadi, \& Kristiaji, 2020). In principle, taxpayers have the right to obtain strict and complete rules for the consequences of an error they have committed. This statement is in line with the principles of nulla poena sine crimine and nullum crimen sine lege, namely that there is no sanction without crime and no crime without a law. Determining the error rate can be a starting point for calculating the penalty or tax interest and compliance level. The OECD (2017) also emphasizes that the tax compliance climate can improve if the tax authorities accurately treat taxpayers according to their compliance level. This administrative sanction draft can apply consistently by linking mistakes with suitable sanctions (Waerzeggers, Hillier, \& Aw, 2019).

The formulation of sanctions in the omnibus law of the Job Creation Law reflects the principle of guilt. The government seems to be trying to distinguish sanctions between serious mistakes and minor mistakes. Academic Paper of the Bill "Tax Provisions and Facilities for Strengthening the Economic" stipulates that administrative sanctions vary by differentiating the amount of interest according to the type of administrative violation. Sanctions issued through the determination process should be higher than the sanctions for payment, reporting, or Tax Return amendment by taxpayers voluntarily (self-assessment).

Through the omnibus law, administrative sanctions issued in the event of an audit require a review by giving a heavier legal degree than the administrative sanctions issued because the taxpayer makes payments, reports, or self-assessment. In line with the reference interest rate as the amount of interest for carrying out tax obligations by self-assessment, the imposition of administrative sanctions due to the stipulation may use a certain additional percentage more significant than the control in the self-assessment mechanism. Thus, it can encourage taxpayers to comply voluntarily. Therefore, the rearrangement of tax administration sanctions in interest and fines has implemented the three indicators above. It means that there are positive signals from tax authorities in designing tax sanctions that encourage voluntary compliance. According to Riyanto et al. (2020), in a policy paper entitled "Critical Notes to Law No. 11/2020 concerning Job Creation," states that the rearrangement of the KUP Law, primarily administrative sanctions in the form of interest, provides a positive vibe for taxpayers because of the classification of sanctions based on violations. The basis used is the reference interest rate, which can change depending on several factors such as inflation and monetary policy. Changes in the benchmark interest rate determine the size of the sanctions imposed.

In addition to realizing fairness to taxpayers, changes in the size and size of administrative sanctions in the form of interest in the KUP Law in the Job Creation Law still consider dire sanctions. The sanctions imposed in this case must have a deterrent effect on the taxpayer who violates the legislation's provisions. The deterrent effect of imposing administrative sanctions in the form of interest refers to Tanzi and Pellechio's (1995) opinion that the imposition of interest sanctions must compensate the government during the late payment period where the total interest is given must exceed the loan interest rate. It can educate taxpayers to fulfill their tax obligations on time and provide justice to all taxpayers. The adjustment of various administrative sanctions in the Job Creation Law will reflect the proportionality aspect, reducing compliance costs to encourage voluntary tax compliance. In the end, improvements to the tax aspect can create legal certainty and Ease of Doing Business, which is the Job Creation Law spirit (Darussalam, 2020). However, it is also necessary to pay attention to how the mechanism for determining the reference interest rate is the basis for calculating administrative sanctions, not to obscure the purpose of simplification. Besides, to avoid mistakes in implementing regulations due to the lack of understanding of officers at the Directorate General of Taxes in calculating sanctions because the calculation of sanctions so far has an easy formulation.

\section{B. The Consequence of Flexible Interest Rate}

The second issue, as a consequence of changes in the interest sanction amount, should also apply to the interest compensation paid by the government under certain conditions. Through the Job Creation Law and rearranging administrative sanctions, the government also rearranged the provisions regarding interest compensation. The KUP Law (UU 28/2007), the imposition of interest compensation at a fixed rate, namely $2 \%$ (two percent) per month for a maximum of 24 months. It gives interest compensation to the taxpayer if the filing of an objection, request for appeal, or request for reconsideration results in a decision that grants partially or entirely. Interest benefits also apply to a decision on the amendment, a decree on a tax assessment deduction, or a decision letter to cancel a tax assessment that grants partially or entirely.

This publication is licensed under Creative Commons Attribution CC BY.

http://dx.doi.org/10.29322/IJSRP.11.09.2021.p11744

WWW.ijsrp.org 
Although it is consistent with the amount of administrative sanction in interest, the interest rate is too large. It is still too high compared to the prevailing interest rates in the domestic market. It can raise taxpayers' behavior to carry out tax planning, intending to obtain benefits from interest returns, which give higher returns than if invested in other investment types. If a taxpayer files an objection to a tax assessment, there is a tendency for the taxpayer to pay the tax assessment amount. When the verdict on the legal remedy grants the taxpayer's objection, the taxpayer is entitled to interest compensation of $2 \%$ (two percent) per month. The interest is higher than if the taxpayer invests their funds in other forms of investment.

Besides, the number of months used to calculate interest compensation is considered incorrect. For example, based on Article 27A paragraph (1) of the KUP Law, the interest compensation for Nil Tax Assessment Letter filed for objection is calculated from the date of the Nil Tax Assessment Letter's issuance until the date issuance of the Objection Decree. However, based on Article 25 paragraph (3), the provisions regarding filing an objection are within 3 (three) months from the date of sending the tax assessment letter. Suppose the taxpayer files an objection at the end of the third month. In that case, the calculation for the taxpayer who receives interest compensation will continue even though the objection settlement process has not yet started. It benefits the taxpayer, and vice versa is detrimental to the state's finances because it must provide interest compensation for a while under the taxpayer's control. The longer the taxpayer submits legal remedies, the greater the interest compensation will be earned.

From the government side, the obligation to pay interest compensation to taxpayers is considered not to reflect the value of money that taxpayers should have if there is no overpayment of taxes. The imposition of interest in return with a fixed interest rate may cause unfairness for one of the parties if the fixed interest rate is lower or higher than the money market's prevailing interest rate. Therefore, the tax omnibus law provisions stipulate that interest compensation is given based on the minister's interest rate per month based on a reference interest rate divided by 12 (twelve). Table 4.3 summarizes the changes to the interest compensation scheme according to the KUP Law and the Job Creation Law as follows:

Table 4.3 Comparison of Interest Rewards according to the KUP Law and the Job Creation Law.

\begin{tabular}{|c|c|c|c|}
\hline Article in KUP Law & The basis for interest compensation & $\begin{array}{l}\text { Amount of interest } \\
\text { compensation according } \\
\text { to UU KUP 28/2007 }\end{array}$ & $\begin{array}{l}\text { Changes in the } \\
\text { Job Creation } \\
\text { Law 11/2020 }\end{array}$ \\
\hline Article 11 paragraph (3) & $\begin{array}{l}\text { Refund of overpayment of tax after one month from } \\
\text { application }\end{array}$ & \multirow[t]{4}{*}{$\begin{array}{l}2 \% \text { per month of the } \\
\text { overpaid tax amount }\end{array}$} & \multirow{4}{*}{$\begin{array}{l}\text { Interest rate per } \\
\text { month* of } \\
\text { overpaid tax } \\
* \text { Reference } \\
\text { interest rate } \div 12\end{array}$} \\
\hline $\begin{array}{l}\text { Article 17B paragraph } \\
\text { (3) }\end{array}$ & $\begin{array}{l}\text { Late issuance of tax overpayment assessment letter } \\
\text { after one month period expires. }\end{array}$ & & \\
\hline $\begin{array}{l}\text { Article 17B paragraph } \\
\text { (4) }\end{array}$ & $\begin{array}{l}\text { Issuance of tax overpayment assessment letter due } \\
\text { to preliminary evidence examination of tax crime: } \\
\text { a. did not continue with the investigation, } \\
\text { b. continued with the investigation, but there was } \\
\text { no prosecution of a tax crime or } \\
\text { c. continued with the investigation or prosecution of } \\
\text { tax crimes, but the verdict declared acquittal }\end{array}$ & & \\
\hline $\begin{array}{l}\text { Article 27B paragraph } \\
\text { (4) } \\
\text { (Added new article) }\end{array}$ & $\begin{array}{l}\text { Refund of overpayment of tax on the filing of } \\
\text { objections, requests for appeal, or requests for } \\
\text { reconsideration that grant part or all of it }\end{array}$ & & \\
\hline
\end{tabular}

Source: Processed by the author

Referring to Table 4.3 above, the interest compensation amount in the form of interest per month refers to the Minister of Finance's reference interest rate. It is valid on the starting date of calculating the interest compensation divided by 12 (twelve). Concerning the period, the determination of the maximum number of months is 24 (twenty-four) months and part of the month counts as one whole month. To provide equal treatment for the amount of interest that taxpayers must pay in the form of administrative sanctions and interest paid by the government in the form of interest compensation, the calculation of the interest compensation uses the reference interest rate mechanism, however, without considering the uplift factor as an additional percentage. This provision can mitigate taxpayers' opportunistic behavior who intend to seek profit from the proposed legal remedies. Taxpayers will not get a result more significant than the interest obtained if they make payments on the tax assessment filed by legal action.

As a consequence of fairness from the provision that it is not permissible to collect payable tax as stated in the Tax Assessment Letter, if the final discussion does not agree, the interest compensation should only apply to the Tax Return, which initially stated overpayment. The amount that becomes the basis for calculating the interest compensation should be tax overpayment, which the taxpayer approves most in the final audit discussion.

Furthermore, the basis for calculating interest compensation requires a review regarding the number of months. The number of months that receive interest compensation is the number of months over which the taxpayer does not control the ongoing legal proceedings. It means counting the number of months from applying for legal action to the issuance of a legal decision. The calculation of projected interest compensation also considers the limitation on the maximum number of months that can be the basis for calculating the interest 
benefit. It is also necessary to consider the rules regarding collecting back the interest compensation that has already been given to the taxpayer, even though the taxpayer is not entitled to the interest compensation. Because until now, there are no rules regarding these provisions, so it requires a legal basis, the Job Creation Law.

Apart from being related to changes in administrative sanctions in the form of interest, Law 11/2020 concerning Job Creation also regulates changes to fines. Table 4.4 summarizes the comparison of administrative fines according to the KUP Law and its amendments in the Job Creation Law as follows:

Table 4.4 Comparison of Administrative Sanctions to Fines according to the KUP Law and the Job Creation Law

\begin{tabular}{|c|c|c|c|c|}
\hline Description & $\begin{array}{l}\text { Article in } \\
\text { KUP Law }\end{array}$ & $\begin{array}{l}\text { Amount of Fines } \\
\text { according to UU KUP } \\
28 / 2007\end{array}$ & $\begin{array}{l}\text { Changes in the Job } \\
\text { Creation Law 11/2020 }\end{array}$ & $\begin{array}{l}\text { Article in } \\
\text { Job } \\
\text { Creation } \\
\text { Law }\end{array}$ \\
\hline $\begin{array}{l}\text { Taxpayers do not submit Tax Returns } \\
\text { within the stipulated time }\end{array}$ & $\begin{array}{l}\text { Article } 7 \\
\text { paragraph } \\
\quad(1)\end{array}$ & $\begin{array}{l}\text { - IDR } 500.000 \text { for VAT } \\
\text { Period Tax Return } \\
\text { - IDR } 100.000 \text { for Other } \\
\text { Income Period Tax Return } \\
\text { - IDR } 1.000 .000 \text { for } \\
\text { Corporate Annual Income } \\
\text { Tax Return } \\
\text { - IDR } 100.000 \text { for } \\
\text { Individual Annual Income } \\
\text { Tax Return }\end{array}$ & No changes & No changes \\
\hline $\begin{array}{l}\text { The taxpayer willingly discloses the } \\
\text { untruth of the data reported in the SPT, } \\
\text { and there has been no investigation. }\end{array}$ & $\begin{array}{l}\text { Article } 8 \\
\text { paragraph } \\
\text { (3) }\end{array}$ & $\begin{array}{l}150 \% \text { of the underpaid tax } \\
\text { amount }\end{array}$ & $\begin{array}{l}150 \% \text { of the underpaid } \\
\text { tax amount }\end{array}$ & $\begin{array}{l}\text { Article } 8 \\
\text { paragraph } \\
\text { (3a) }\end{array}$ \\
\hline $\begin{array}{l}\text { 1. Entrepreneurs who have established } \\
\text { themselves as Taxable Entrepreneurs } \\
\text { (PKP) but do not make tax invoices or } \\
\text { make tax invoices, but not on time. } \\
\text { 2. PKP does not fill out invoices } \\
\text { completely }\end{array}$ & $\begin{array}{l}\text { Article } 14 \\
\text { paragraph } \\
\text { (4) }\end{array}$ & $2 \%$ of the tax base & $1 \%$ of the tax base & $\begin{array}{c}\text { Article } 14 \\
\text { paragraph (4) }\end{array}$ \\
\hline $\begin{array}{l}\text { The objection results in a decision that } \\
\text { either rejects or partially grants it }\end{array}$ & $\begin{array}{l}\text { Article } 25 \\
\text { paragraph } \\
\quad(9)\end{array}$ & $\begin{array}{l}50 \% \text { of the total tax based } \\
\text { on the objection decision is } \\
\text { reduced by the tax paid } \\
\text { before filing an objection }\end{array}$ & No changes & No changes \\
\hline $\begin{array}{l}\text { Application for appeal results in a } \\
\text { decision that either rejects or partially } \\
\text { grants it }\end{array}$ & $\begin{array}{l}\text { Article } 27 \\
\text { paragraph } \\
\quad(5 \mathrm{~d})\end{array}$ & $\begin{array}{l}100 \% \text { of the total tax based } \\
\text { on the appeal decision } \\
\text { reduced by the tax paid } \\
\text { before filing an appeal }\end{array}$ & No changes & No changes \\
\hline $\begin{array}{l}\text { Termination of a criminal investigation } \\
\text { by the Attorney General at the request } \\
\text { of the Minister of Finance }\end{array}$ & $\begin{array}{l}\text { Article 44B } \\
\text { paragraph } \\
\text { (2) }\end{array}$ & $\begin{array}{l}4 \text { (four) times the amount } \\
\text { of tax not paid or underpaid } \\
\text { or for which there is no } \\
\text { refund }\end{array}$ & $\begin{array}{l}3 \text { (three) times the } \\
\text { amount of tax not paid } \\
\text { or underpaid or for } \\
\text { which there is no refund }\end{array}$ & $\begin{array}{c}\text { Article 44B } \\
\text { paragraph (2) }\end{array}$ \\
\hline
\end{tabular}

Source: Processed by the author

According to Table 4.4, there is no change in the sanctions for non-timely reporting of Tax Returns according to the regulations. The sanctions applied are still a fixed amount with a different amount based on the Tax Return type. Other countries such as Denmark, Hungary, and the United Kingdom also apply the same provisions (Seer \& Wilms, 2015). Furthermore, there is a decrease in sanctions for disclosing untruths before the investigation and reducing Taxable Entrepreneurs' sanctions related to the preparation and filing of tax invoices in the omnibus law. In line with the reduction in sanctions, the OECD Managing and Improving Tax Compliance Guidance Note 2004 states that providing taxpayers' incentives can positively impact taxpayer compliance. It certainly will encourage taxpayers to make voluntary disclosures.

Furthermore, it relates to the reduction of sanctions for terminating the investigation of tax criminal offenses. The provisions of Article 44B of the KUP Law explain that the purpose and purpose of implementing the tax law are not to criminalize taxpayers but to collect taxes effectively and efficiently (Mulyodiwarno, 2007). Decreasing sanctions can further encourage more effective and efficient tax collection (Chairunnisa, 2020). Referring to the Academic Paper of the Bill "Tax Provisions and Facilities for Strengthening the Economic," states that reviewing the imposition of administrative sanctions should make it a lower fixed rate. To provide learning value 
and a deterrent effect on administrative violations requires sanctions but with an amount that still considers the taxpayer's burden. Administrative sanctions that are too large can affect business continuity.

Furthermore, related to changes in administrative sanctions in the form of increases. Table 4.5 summarizes the comparison of the increase in administrative sanctions under the KUP Law and the amendments in the Job Creation Law as follows:

Table 4.5 Comparison of Increase in Administrative Sanctions according to the KUP Law and the Job Creation Law

\begin{tabular}{|c|c|c|c|c|}
\hline Description & $\begin{array}{l}\text { Article in } \\
\text { KUP Law }\end{array}$ & $\begin{array}{l}\text { Amount of } \\
\text { Increases } \\
\text { according to } \\
\text { KUP Law } \\
\text { 28/2007 }\end{array}$ & $\begin{array}{l}\text { Changes in the } \\
\text { Job Creation } \\
\text { Law 11/2020 }\end{array}$ & $\begin{array}{l}\text { Article in Job } \\
\text { Creation Law }\end{array}$ \\
\hline $\begin{array}{l}\text { Taxpayers who, due to their negligence, do not submit } \\
\text { Tax Return or submit Tax Return, but the contents are } \\
\text { incorrect/incomplete or attach information whose } \\
\text { contents are incorrect so that it may cause losses to } \\
\text { state revenue if the negligence is the first time }\end{array}$ & $\begin{array}{c}\text { Article } \\
13 \mathrm{~A}\end{array}$ & $\begin{array}{l}\text { An increase of } \\
200 \% \text { from the } \\
\text { amount of } \\
\text { underpaid tax }\end{array}$ & Deleted & $\begin{array}{l}\text { No changes. } \\
\text { Furthermore, the } \\
\text { regulation is in } \\
\text { Amendment of } \\
\text { Article } 38\end{array}$ \\
\hline $\begin{array}{l}\text { Suppose the audit has taken place, but there has been } \\
\text { no issuance of a Tax Assessment. In that case, with } \\
\text { their awareness, taxpayers can disclose the incorrect } \\
\text { filing of the Tax Return in a separate report, and the } \\
\text { disclosure results in underpaid taxes. }\end{array}$ & $\begin{array}{c}\text { Article } 8 \\
\text { paragraph } \\
(5)\end{array}$ & $\begin{array}{l}\text { An increase of } \\
50 \% \text { from the } \\
\text { amount of } \\
\text { underpaid tax }\end{array}$ & $\begin{array}{l}\text { An increase of } \\
100 \% \text { from the } \\
\text { amount of } \\
\text { underpaid tax }\end{array}$ & $\begin{array}{l}\text { Article } 8 \text { paragraph } \\
\text { (5) with addition } \\
\text { Article } 8 \text { paragraph } \\
\text { (5a) }\end{array}$ \\
\hline
\end{tabular}

Source: Processed by the author

According to Table 4.5, two changes made to administrative sanctions increase in the Job Creation Law, including eliminating Article 13A and changes to the sanction scheme for Article 8 paragraph (5) of the KUP Law. Article 13A of the KUP Law regulates the increase in sanctions for taxpayers' negligence for not submitting or submitting Tax Return, which contents are incomplete or attach incorrect information. Thus it can cause losses to state revenues, as long as the negligence is first. This provision adheres to the ultimum remedium principle. However, if the negligence is an act after the first time, the taxpayer will be subject to criminal sanctions following Article 38 of the KUP Law. Article 38 of the KUP Law regulates that criminal sanctions are a fine of at least 1 (one) time the amount of tax payable that is underpaid and a maximum of 2 (two) times the amount of tax payable that is not paid or is underpaid. Also, imprisonment for at least 3 (three) months or a maximum of 1 (one) year. The elimination of Article 13A is in line with the amendment of Article 38 of the KUP Law. The sanctions will apply to all taxpayers' negligence, whether for the first time or not. It means that every act of negligence committed by a taxpayer will be subject to criminal sanctions.

Furthermore, Article 8 paragraph (5) of the KUP Law states that for the disclosure of untruth in the Tax Return, which causes tax underpayment after the audit and the tax authorities have not issued a Tax Assessment. Thus, the taxpayer is subject to an increase in $50 \%$ (fifty percent) tax sanctions incurred low payment. However, in the Job Creation Law, the change in sanctions becomes an interest sanction equal to the interest rate per month set by the Minister of Finance from underpaid taxes. The change in the sanction scheme of Article 8 paragraph (5) of the KUP Law shows the government's efforts in implementing the time value of money concept. Drake and Fabozzi $(2009$, p. 3) state that the time value of money concept implies that the present value of money will be different from the value of money in the future, "A dollar today is not worth a dollar tomorrow or next year." Then, as compensation for the uncertainty in value, it is appropriate to apply interest.

In the above case, the underpaid tax on the untruth disclosure is the amount of pending state tax revenue so that the interest will act as compensation for the receipt's postponement. In line with Leif Mutén (2001), which states that if the state experiences a loss from the time value of money due to delayed tax revenue, the taxpayer should only be subject to "interest" obligations (Darussalam \& Septriadi, 2007). Thus, in general, changes to tax administration sanctions in taxation clusters in the Job Creation Law are an accurate strategy taken by the government to encourage voluntary tax compliance. Nevertheless, it is still necessary to evaluate the effectiveness of the sanctions that are still in effect to create a more proportional and fair system of tax administration sanctions.

\section{Objetive of The Omnibus Law}

The third issue these study covers is the next objective of the omnibus law's idea concerning the amendment of the KUP Law, increasing legal certainty. Researchers highlight at least 4 (four) issues of General Tax Provisions and Procedures in Law No. 11 of 2020 concerning Job Creation.

The first issue is to provide legal certainty for tax penalties regulations, which have resulted in decisions that are no longer issued tax assessments. This policy removes Article 13 paragraph (5) and Article 15 paragraph (4) of the KUP Law. Previously, Law No. 28 of 2007 concerning KUP stipulates that if the five-year period has expired, the tax authorities can still issue an underpayment tax assessment plus administrative sanctions in the form of interest of $48 \%$ (forty-eight percent) of the amount of tax not paid or underpaid. Moreover, after five years, the taxpayer is subject to a criminal offense for committing a criminal offense in the field of taxation or other criminal acts that can cause losses to state revenues based on a court decision with permanent legal force. 
Based on the memory of the explanation of Article 13 paragraph (5) and Article 15 paragraph (4), Law No. 28 of 2007 states that if taxpayers are investigating criminal offenses in the field of taxation to determine losses to state revenue, the tax authorities have not issued a tax assessment. To determine whether the taxpayer has indeed committed a crime in the field of taxation, it must be evident through a court process that can take more than five years. The possibility may occur that the taxpayer's investigation by the Civil Servant Investigator, but not prosecuted by the public prosecutor based on the criminal tax sanction. For example, the court has convicted a taxpayer for smuggling, which indicates that the court's decision has not taxed some tax objects. Therefore, to recover the payable tax, if a taxpayer commits a criminal offense in the field of taxation or other criminal acts that may cause losses to state revenue, the tax authorities can still issue an underpayment tax assessment. Based on a court decision with permanent legal force, the issuance of an assessment letter for underpayment of tax plus administrative sanctions in the form of interest of $48 \%$ of the amount of unpaid or underpaid tax even though it has exceeded five years.

In essence, the issuance of Tax Underpayment Assessment and Additional Tax Underpayment Assessment (Surat Ketetapan Pajak Kurang Bayar Tambahan; SKPKBT) aims to recover taxes owed that were not paid or were underpaid. Elucidation of Article 62 of Government Regulation Number 74 of 2011, in the case of criminal offenses in the field of taxation related to Article 38 or Article 39 of the KUP Law, taxpayers must pay the amount of loss to state revenue amount of unpaid or underpaid taxes. Thus "taxes that are not paid or underpaid" as the basis for the issuance of Tax Underpayment Assessment and Additional Tax Underpayment Assessment based on Article 13 paragraph (5) and Article 15 paragraph (4) of the KUP Law originate from problems or violations with the same facts related to losses to state income. It is the intent of the criminal tax judge in his decision. Therefore, with the issuance of Tax Underpayment Assessment and Additional Tax Underpayment Assessment related to a tax criminal judge's verdict with permanent legal force, there will be a problem or violation with the same facts a punishment or be tried twice. The Circular of the Chief Justice of the Supreme Court No. 2 of 2019 emphasizes the importance of ending tax law enforcement efforts by enforcing the litis finiri oportet principle. That is, the verdict of a criminal judge in a tax crime aims to end an effort to enforce the law. Suppose a taxation issue has been tried and decided by a criminal judge's decision with permanent legal force. In that case, it is no longer justified to take other law enforcement actions because a criminal judge's decision in a tax crime is to end an effort to enforce the law (litis finiri oportet). The applicable principle is ultimum remedium.

Furthermore, the litis finiri oportet principle is in line with the principle of ne bis in idem. According to Baker and Pistone (2020), the principle of ne bis in idem or the prohibition of double jeopardy in tax law is part of legal principles that are the foundation for the protection of taxpayers' rights, apart from the Audi Altera partem principle, the proportionality principle, and the Nemo tenetur principle (nonself-incrimination). The principle of ne bis in idem is also a taxpayer's fundamental right to guarantee protection. The goal is so that taxpayers avoid the obligation to defend themselves twice for the same tax problem or violation. Thus, the omnibus law related to eliminating provisions for the issuance of Tax Underpayment Assessment and Additional Tax Underpayment Assessment to collect unpaid or underpaid taxes for violations with the same facts and previously decided by the tax criminal judge is the right step. Besides increasing the certainty of the penalties imposed, adopting the principle of ne bis in idem in tax law can present a tax collection system that considers and respects human rights. It is also in line with universal legal norms found in Indonesia's criminal or civil law system, namely Article 76 of the Criminal Code and Article 1917 of the Civil Code. It will be in line with the principle of ultimum remedium in tax law, where the tax penalty decision is to cover or as a last resort in the process of tax dispute resolution and tax law enforcement.

The second issue related to increasing legal certainty is arranging the expiration of a Tax Collection Letter (Surat Tagihan Pajak; STP) issuance by the Directorate General of Taxes to 5 (five) years. The scope of this amendment is in Article 14 paragraph (5b) and paragraph (5c), which states that the issuance of a Tax Collection Letter is not later than 5 (five) years after the time the tax becomes due or the end of the Tax Period, part of the Tax Year, or Tax Year. Furthermore, exemption from the stipulation of the issuance period as intended includes (i) Tax Collection Letter for administrative sanctions for collection interest (Article 19 paragraph (1)) issued no later than the expiration of the Tax Underpayment Assessment and Additional Tax Underpayment Assessment billing, and Correction Decree, Objection Decree, Decision Appeals, as well as Judgment on Reconsideration which causes the amount of tax accrued to increase; (ii) Issuance of a Tax Collection Letter for a fine of 50\% (Article 25 paragraph (9)) no later than 5 (five) years from the date of issuance of the Objection Decision if the taxpayer does not file an appeal; and (iii) Issuance of a Tax Collection Letter for collection fines of 100\% (Article 27 paragraph (5d)) no later than 5 (five) years from the date the Tax Court judge reads the decision on appeal in an open court to the public.

The third issue is the existence of an arrangement that the Director-General of Taxes can issue a Tax Collection Letter to collect back interest compensation, which should not be the taxpayer's right. This policy's scope lies in the addition of Article 14 paragraph (1) letter h, in which Law 28/2007 does not stipulate such provisions. More specifically, the tax authorities can issue a Tax Collection Letter in terms of (i) issuance of a decision; (ii) acceptance of the award; or (iii) discovery of data or information indicating that there is interest compensation which should not be the right of the taxpayer. The purpose of issuing a Tax Collection Letter to collect back the interest compensation is to provide legal certainty and ease of administration for collecting interest compensation, which has not been clear. In addition to changes in provisions regarding the issuance of tax assessment, the fourth issue, similar amendments also occur in regulations regarding Tax Returns. Based on Article 13 paragraph (4) of the KUP Law, which has been amended by Law 11/2020 concerning Job Creation, stipulates that the taxpayer's tax payable amount in the reported Tax Return will be certain following the provisions of the taxation legislation. In this case, if the tax authorities do not issue a tax assessment within five years unless the taxpayer commits a crime in the field of taxation. It is an effort by DGT to increase voluntary taxpayer compliance and appreciate taxpayers who have complied.

This publication is licensed under Creative Commons Attribution CC BY.

http://dx.doi.org/10.29322/IJSRP.11.09.2021.p11744

wWw.ijsrp.org 


\section{CONCLUSION}

Taxation regulations in Indonesia are very complex and overlapping, so they tend to create legal uncertainty and multiple interpretations. Amendments to Law No. 28 of 2007 concerning General Tax Provisions and Procedures (UU KUP) in Law No. 11 of 2020 concerning Job Creation adopts the idea of the omnibus law, which includes amendments, deletions, and additions of several articles. The main objective of the regulatory amendments is to encourage voluntary compliance and to increase legal certainty. Steps to achieve voluntary tax compliance are rearranging administrative tax sanctions (interest, fines, increases) and lower interest returns based on the reference interest rate (flexible rate) and the uplift factor component. The rearrangement of tax administration sanctions has also fulfilled three indicators: the time value of money, proportionality according to the error level, and the culpability principle. It shows the government's desire to provide justice to taxpayers with different levels of violations. In addition to realizing fairness and providing convenience to taxpayers, changes in the formulation of administrative sanctions in the Job Creation Law also remain in the thought of sanctions that have a deterrent effect.

Furthermore, steps to achieve legal certainty include (i) the tax authorities cannot issue a tax assessment on tax penalties that have resulted in a decision; (ii) the issuance of a Tax Collection Letter that expires 5 (five) years; (iii) Issuance of Tax Collection Letter to collect interest compensation which should not be the right of the taxpayer; and (iv) Tax Returns are inevitable for five years. Amendments to the KUP Law in the Job Creation Law will positively impact more optimal tax revenue and reduce compliance costs and tax avoidance. The last estuary, which is the target and other objectives, improves the country's economy. However, the amendment to the provisions will not affect the voluntary tax compliance level if the tax administration does not support the detection of noncompliance (Riyanto, 2020). Therefore, the implementing regulations must be clear and not cause multiple interpretations because regulations with a gray area can lead to increased compliance costs. Implementing instructions need to be clear and include examples, a better understanding while still prioritizing socialization.

\section{REFERENCES}

[1] Ali, M., Fjeldstad, O., \& Sjursen, I. (2014). To Pay or Not to Pay? Citizens' Attitude Toward Taxation in Kenya, Tanzania, Uganda, and South Africa. World Development, Vol. 64, 828-842.

[2] Apeldoorn, V. (1990). Pengantar Ilmu Hukum. Jakarta: Pradnya Paramita.

[3] Audzevicius, R. (2011). Proportionality in Tax Disputes: Lithuanian Court Practice. The University of London. Retrieved from https://sasspace.sas.ac.uk/4718/1/Ramunas_Audzevicius_MA_Taxation_dissertation.pdf

[4] Baker, P., \& Pistone, P. (2020). Observatory on the Protection of Taxpayers' Rights. IBFD.

[5] Bertea, S. (2008). Towards A New Paradigm of Legal Certainty. Legisprudence, Vol. 2, No. 1, 25-45.

[6] Chairunnisa, D. R. (2020). Meninjau Perubahan Sanksi Pajak dalam UU Cipta Kerja. Retrieved from DDTC News: https://news.ddtc.co.id/meninjauperubahan-sanksi-pajak-dalam-uu-cipta-kerja-24833\#: :text=Pasal\%2038\%20UU\%20KUP\%20menyebutkan,atau\%20paling\%20lama\%201\%20(satu)

[7] Crawford, D. (2013). Chapter 7: Filing and Payment. In Detailed Guidelines for Improved Tax Administration in Latin America and the Caribbean. USAID Leadership in Public Financial Management (LPFM).

[8] Creswell, J. W. (2014). Research Design: Qualitative, Quantitative, and Mixed Method Approaches. California: SAGE Publications, Inc.

[9] Darussalam. (2020). Makna Positif Klaster Perpajakan dalam UU Cipta Kerja. Retrieved from DDTC News: https://news.ddtc.co.id/makna-positif-klasterperpajakan-dalam-uu-cipta-kerja-24505

[10] Darussalam. (2020). Membangun Moral Pajak. Retrieved from DDTC News: https://news.ddtc.co.id/membangun-moral-pajak-23197

[11] Darussalam, \& Septriadi, D. (2007). Catatan Tentang Kebijakan Sanksi Perpajakan Sejak Undang-Undang KUP 1983 Hingga Undang-Undang KUP 2007. Inside Tax. Jakarta: DDTC.

[12] Darussalam, Septriadi, D., \& Kristiaji, B. B. (2020). Policy Note: Omnibus Law Ketentuan \& Fasilitas Perpajakan Untuk Penguatan Perekonomian: Suatu Catatan. Jakarta: DDTC Fiscal Research.

[13] Diaz, A. L. (2016). Comment Report: Penalties, Interest, and Surcharges under the Perspective of Proportionality. In R. Seer, \& A. L. Wilms, Surcharges and Penalties in Tax Law (pp. 77-83). Netherlands: IBFD.

[14] Drake, P. P., \& Fabozzi, F. J. (2009). Foundations and Applications of the Time Value of Money. New Jersey: John Wiley \& Sons, Inc.

[15] Garner, B. A. (2009). Black's Law Dictionary (9th ed.). United States of America: West Publishing Co.

[16] Gordon, R. K. (1996). Law of Tax Administration and Procedure. In V. Thuronyi, Tax Law Design and Drafting. Washington D.C.: International Monetary Fund.

[17] Lane, A. (2015). Proportionality and Penalties. Retrieved from Edge Tax: https://www.edge-tax.com/library/proportionality-and-penalties/

[18] McLure, Charles E. (2019). Taxation. Retrieved from Encyclopaedia Britannica: https://www.britannica.com/topic/taxation

[19] Mertokusumo, S. (1986). Mengenal Hukum. Yogyakarta: Liberty.

[20] Mulyodiwarno, N. (2007). Catatan Tentang Kebijakan Sanksi Perpajakan Sejak Undang-Undang KUP 1983 Hingga Undang-Undang KUP 2007. In Inside Tax. Jakarta: DDTC.

[21] Muten, L. (2001). Taxation of Interest in the European Union. Intereconomies.

[22] Needham, A. (2012). The Principle of Proportionality in Default Surcharge Penalties. Retrieved from Bloomsbury Publishing: https://www.bloomsburyprofessionalonline.com/applib/newsitem/154/the-principle-of-proportionality-in-default-surcharge-penalties

[23] OECD. (2014). Addressing The Tax Challenges of The Digital Economy.

[24] OECD. (2017). IMF/OECD Reports for the G20 Finance Ministers.

[25] OECD. (2017). The Changing Tax Compliance Environment and the Role of Audit. Paris: OECD Publishing.

[26] OECD. (2019). Tax Morale: What Drives People and Businesses to Pay Tax? Paris: OECD Publishing.

[27] Owens, J. (2019). Cooperative Compliance. In Tax Adviser Magazine.

[28] Pistone, P. (2019). Fundamentals of Taxation: An Introduction to Tax Policy, Tax Law and Tax Administration. Amsterdam: IBFD.

[29] Prayogo, R. T. (2016). Penerapan Asas Kepastian Hukum dalam Peraturan Mahkamah Agung Nomor 1 Tahun 2011 Tentang Hak Uji Materiil dan dalam Peraturan Mahkamah Konstitusi Nomor 06/PMK/2005 Tentang Pedoman Beracara dalam Pengujian Undang-Undang. Jurnal Legislasi Indonesia, Vol. $13(2)$.

[30] Riyanto, S. (2020). Kertas Kebijakan: Catatan Kritis terhadap UU No. 11 Tahun 2020 tentang Cipta Kerja. Jogjakarta: Fakultas Hukum Universitas Gadjah Mada.

[31] Rosdiana, H., \& Irianto, E. S. (2014). Pengantar Ilmu Pajak: Kebijakan dan Implementasi di Indonesia (3rd ed.). Jakarta: Rajawali Pers. 
[32] Rowell, G., \& Flood, J. (2017). Tax Penalties. Sweet \& Maxwell, Limited.

[33] Seer, R., \& Wilms, A. L. (2015). Surcharges and Penalties in Tax Law. Amsterdam: IBFD.

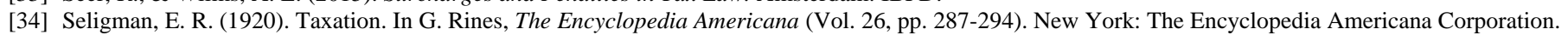

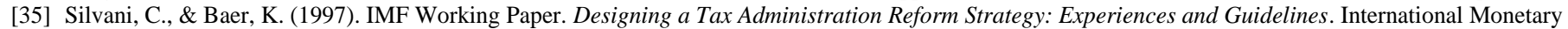
Fund.

[36] Smith, A. (1776). An Inquiry into the Nature and Causes of the Wealth of Nations. Paris: Feedbooks.

[37] Sumardjono, M. S. (1997). Kepastian Hukum dalam Pendaftaran Tanah dan Manfaatnya Bagi Bisnis Perbankan dan Properti. Seminar Kebijaksanaan Baru di Bidang Pertanahan, Dampak dan Peluang Bagi Bisnis Properti dan Perbankan. Jakarta.

[38] Tanzi, V., \& Pellechio, A. (1995). IMF Working Paper. The Reform of Tax Administration. International Working Paper.

[39] Torgler, B. (2005). Tax Morale and Direct Democracy. European Journal of Political Economy, 525-531.

[40] Vanistendael, F. (1996). Chapter 2: Legal Framework for Taxation. In V. Thuronyi, Tax Law Design and Drafting. International Monetary Fund.

[41] Waerzeggers, C., Hillier, C., \& Aw, I. (2019). Designing Interest and Tax Penalty Regimes. IMF Legal Department.

[42] Wagner, A. (1883). Three Extracts on Public Finance. In R. A. Musgrave, \& A. T. Peacock, Classics in the Theory of Public Finance (pp. 1-15). London: The Macmillan Press Ltd.

[43] Wagner, C., Kawulich, B. B., \& Garner, M. (2012). Doing Social Research: A Global Context. McGraw-Hill Education.

\section{AUTHORS}

First Author - Dr. Prianto Budi Saptono, Lecturer, Universitas Indonesia, prianto.budi@ gmail.com

Second Author - Cyntia Ayudia, Researcher, Pratama-Kreston Tax Research Institute, cyntia.ayudia@gmail.com

Third Author - Muhammad Akbar Aditama, Researcher, Pratama-Kreston Tax Research Institute, akbar.aditama@gmail.com

Correspondence Author - Prianto Budi Saptono, prianto.budi@gmail.com, +6281190618 